\title{
THE RELATIONSHIP BETWEEN LANGUAGE LEARNING STRATEgIES AND Vocational LEARNERS’ EFL PROFICIENCY
}

\author{
Hilda Yustitiasari, Esti Junining, Sahiruddin \\ Magister Ilmu Linguistik Universitas Brawijaya \\ mauludia1985@gmail.com, esti_junining@yahoo.com, shrdn@ub.ac.id
}

\begin{abstract}
Language learning strategies (LLS) are perceived as tools for teacher to educate the learners behave self-directed learning. It also known, improving language proficient. In the case of vocational college students, they practically use self-directed learning in learning English outside classroom since they should pass the TOEFL test after the internship as the requirement of graduation. Hereby, this study identifies: (1) the frequently language learning strategy used by vocational college learners, (2) the relationship between language learning strategy and English proficiency, (3) the strategy used by learners which could predict learners proficient. The participant is 52 students of Politeknik Kota Malang in 2016- 2017 academic year which done the TOEFL test and willing to complete the Strategy Inventory of Language Learning (SILL). This study employed quantitative approach and correlational research as the research design to identify the relationship between variables. There are six strategies of language learning strategies by Oxford (1990) as the independent variables (predictors) and English proficiency (criterion) as the dependent variable. Therefore, multiple regression analysis employed in this study. The result showed that metacognitive strategy reported highly used by learners. While compensation, cognitive, social strategies reported medium used by learners. The low strategy used was affective and memory strategies. Although, language learning strategy cannot simultaneously predict the English proficiency there is one strategy that can be used to predict English proficiency, namely compensation strategy.
\end{abstract}

Keywords: Language Learning Strategies, EFL Learners, English Proficiency

\section{INTRODUCTION}

English language learning in the university experienced paradigm from teacher centered learning to students centered learning. Therefore, the teacher leads learners to build self-directed learning. Selfdirected learning itself reflects learners' ability or skill to get the initiative in setting their own learning goals and arranging the English learning (Min and Pey, 2010). It is important for the teacher to guide learners to exercise their self-directed learning. The tool used by learners in practicing their self-directed learning is language learning strategy (Min and Pey, 2010).

Language learning strategies implemented and applied by the teacher for students can give an impact to the effectiveness of teaching and learning a language in class and obtain learners' achievement in English proficiency. Hao and Nai (2015) stated that the instructor should provide the language learning strategies to fulfill the learners' needs since the learners precede information in different ways and different learning goals. The study about the challenge for learners and teachers in English for Specific Purpose (ESP) course by Saliu (2013) also stated that the teacher should be aware to the learner's needs in the English course. Therefore, there should be a harmony between the learner strategy in learning a language with the instruction and content or materials from the teacher. The process of building the language learning's material and the material development should start with an investigation on the learner's language learning strategies in order to designate learner-centered learning (Dabaghi and Akvan, 2014). Hereby, learners should determine their priority needs in learn English and the teacher should investigate the learners' strategy in learning a language.

In investigating the learners' strategy in language learning, this investigation could be assessed using certain instrument which measures language learning strategies. This is in line with Murcia (2015, p. 49) confirming the standard instruments to be used by English for Specific Purposes (ESP) practitioners to determine learners' language learning approaches. There are some assessments of language learning strategies based on the taxonomy by O'Malley's (1985), Rubin (1987), Oxford (1990) and Stern (1992). Among four taxonomy language learning strategy, the classification by Oxford (1990) is the most comprehensive (Ellis, 1994; Harya, 2017; Rachmawati, 2013). Oxford's (1990) taxonomy of language learning strategies is classified into six strategies: memory, cognitive, compensation, metacognitive, affective and social strategies. Based on such taxonomy, Oxford (1990) developed the instrument to assess the language learning strategy known as Strategy Inventory of Language Learning (SILL).

This taxonomy or the instrument has been broadly used in many researches since language learning strategy itself is an appropriate strategy and as a tool of self-directed learners in learning 
language. Min and Pey (2010) and Oxford (1990) also stated that language learning strategies is important since it could improve language proficiency and develop communicative competence.

Research on the relationship between LLS and English proficiency in outside Indonesia or abroad involved various participants with different majors or study programs, and it is different from the research conducted in Indonesia. Dai (2016) investigated students of the Tianjin Sino-German vocational-technical college China. Hao \& Nai (2015) investigate the learners from Tzu Chi College of Technology. Meanwhile, research in Indonesia focused more in English departement and management department. Rismayana (2017) and Rachmwaty et. al (2018) examined English department's students, and Hayati (2015) investigated the management department student of STIENAS Samarinda. Therefore, the present study investigated LLS and English proficiency for vocational college students

In this context, the objectives of this study are: first, the language learning strategies used by the EFL learner of vocational college in learning the English subject outside the classroom during the internship. Second, examine the relationship between language learning strategies and English proficiency. The last, examine the strategy which could predict the English proficiency by EFL learners.

\section{MATERIALS AND METHOD}

This study is aimed to find the correlation between language learning strategies and Indonesian learners' EFL proficiency. There is more than one independent variable in this study which consisted of six language learning strategies by Oxford (1990). The variables are 1) memory strategies (X1), 2) cognitive strategies (X2), 3) compensation strategies (X3), 4) metacognitive strategies (X4), 5) affective strategies (X5), and 6) social strategies (X6). The dependent variable of this study is the English proficiency which is denoted as letter Y.

The present study involved the 52 students who met the criteria as set out as follows: the students are required to complete the English course, be voluntarily participated in this study by completing SILL questionnaire, and have done the TOEFL test. Thus

Oxford's (1990) SILL questionnaire has been translated into Bahasa Indonesia to minimize the problem in the participant's understanding of each question. Therefore, the Indonesian version of SILL in this study was adopted from Rachmawati (2015) as it showed high reliability of the data with the score above 0.9 .

However, the items of SILL instruments were valid since there were no items deleted and the significant of all the items were under 0.05. According to Silalahi (2015), the table of instrument measurement by Cronbach's Alpha showed that the reliability data in the range of 0.6 until 0.7 can be accepted, and if it is in the range of $0.7-0.9$ over, it showed a good reliable data. In this research, the reliability of the SILL was Cronbach's Alpha was .96. This demonstrated that the instrument used in this study had high reliability and the results of this study can be trusted and reliable.

In terms of TOEFL test, the test was done and organized by the test center at POLTEKOM, while the researcher collected the test scores from the test administrator. The TOEFL test was assumed to be reliable as it has been widely used as instrument in other previous studies. TOEFL also the standard of English measurement used by the company, government institution and included as an English learning program in Indonesia.

The data collection of the main study was conducted in some steps: first, the researcher asked permission to the participants for an agreement to fill the questionnaire. Second, the researcher explained about the purpose of the survey and gave the due date for students to accomplish the questionnaires. The researcher used Google form as the media for the participants to fill in the questionnaire. This is aimed to make the participants have much time and easier to fill the questionnaire since the Google form can be accessed from smartphone. After that, the researcher collected the TOEFL score and continued to the next step of the research, that is conducting the data analysis

The procedures of analysis are descriptive statistic and inferential statistic. In descriptive statistics, the mean score of SILL questionnaire result was computed in order to determine language learning strategies used by all participants. Furthermore, in inferential statistic, the researcher examines the correlation between variables being investigated. The researcher determined the classic assumption before doing regression analysis. Based on Silalahi (2015) a model of regression analysis should theoretically fulfill requirements: Normal distribution, the variables are non-multicollinearity and the data is homoscedasticity.

First, the data were all normally distributed as assessed through the values. Based on Field (2009), the data normally distributed if the value were not greater than 1.96 or 2.58 Second, the data were fulfilled the assumption of non- multicollinearity since the VIF value is less than 10. Based on the Field 
(2009) that if VIF are below 10 can be concludes that there is non-multicollinearity within the data. Third, the data were fulfilled the assumption of homoscedasticity since there is no significant value which there is no homoscedasticity in residual, based on Field (2009) that the residuals at every predictors should have the same variance or homoscedasticity (Sig. $>\square=0.05$ ). Thus, the data of this research are fulfilled, and the classic statistical assumptions were met so that the parametric test in this study as further multiple regression analyses could be run.

\section{RESULTS AND DISCUSSION}

\subsection{The Description Statistic of Language Learning Strategy Categorization ACROSS VOCATIONAL COLLEGE'S EFL LEARNERS}

Based on table 1, there were six kinds of LLS use employed by EFL learners. Generally, the third most LLS used by the high proficient learners were metacognitive strategies, compensation strategies and cognitive strategies. Social strategies, affective strategies, and memory strategies were the least used strategies in this context.

\begin{tabular}{|l|l|l|l|}
\hline Category of language learning strategies & Rank & Mean & SD \\
\hline Metacognitive strategies & 1 & 3.36 & 0.78 \\
\hline Compensation strategies & 2 & 3.30 & 0.75 \\
\hline Cognitive strategies & 3 & 3.37 & 0.56 \\
\hline Social strategies & 4 & 3.24 & 0.89 \\
\hline Affective strategies & 5 & 3.23 & 0.86 \\
\hline Memory strategies & 6 & 3.19 & 0.73 \\
\hline
\end{tabular}

Table 1 The Descriptive Statistic of Language Learning Strategy across Vocational College's EFL Learners

The compensation strategy and cognitive strategies are classified in direct strategy while metacognitive strategy is included in indirect strategy. In this situation, EFL learners used the use of metacognitive strategies reflected the tendency for these learners to overview the known material of language, plan the language task and evaluate their own learning. Meanwhile, the compensation strategy is used by guessing the linguistics clues and switching into second language with gesture or using synonymy. The last, high proficient learners used cognitive strategies in which they were practicing by repeats and recombines the language materials; and creating structure input and output by taking notes, summarize, highlight and translate the written text across language.

\subsection{The Relationship Between Language Learning Strategy AND English Proficiency ACROSS PARTICIPANTS}

The table 2 showed that the correlation coefficient $\mathrm{R}$ value was 0.429 indicating that the degree of simultaneous correlation between LLS and English. Thus, it was found that there was a positive moderate correlation between language learning strategies (LLS) and English proficiency.

\begin{tabular}{|l|l|l|l|l|l|l|l|l|l|}
\hline \multirow{2}{*}{ Model } & $\mathrm{R}$ & \multirow{2}{*}{$\mathrm{R}^{2}$} & $\begin{array}{l}\text { Adjusted } \\
\mathrm{R}^{2}\end{array}$ & & $\begin{array}{l}\text { Std. Error of } \\
\text { the Estimate }\end{array}$ & & \multicolumn{3}{|l|}{ Change Statistics } \\
\cline { 6 - 9 } & & & & & & & & \\
\end{tabular}

Table 2 The Summary of Linier Regression Analysis of TOEFL Score as Criterion Variable and Language Learning Strategy as Predictor Variable 
Meanwhile, the distribution R2 (0.184) demonstrated that the result of coefficient determination is $18.4 \%$. In other words, LLS accounted for $18.4 \%$ of TOEFL score. While the rest $81,6 \%$ is explained by other variables which are not included in this research.

\begin{tabular}{|l|l|l|l|l|l|l|}
\hline \multicolumn{2}{|l|}{ Model } & Sum of Squares & Df & Mean Square & F & Sig. \\
\hline 1 & Regression & 22811.457 & 6 & 3801.909 & 1.695 & $\mathbf{1 4 4}^{\mathbf{b}}$ \\
\cline { 2 - 7 } & Residual & 100958.601 & 45 & 2243.524 & & \\
\cline { 2 - 7 } & Total & 123770.058 & 51 & & & \\
\hline
\end{tabular}

a. Dependent Variable: TOEFL

b.Predictors: (Constant), Social, Compensation, Memory, Cognitive, Affective, Metacognitive

Table 3 The ANOVA Test Result of Multiple Regression Analysis between LLS and English Proficiency

The table 3 showed the distribution pvalue $0.144>0.05$ in which this leads to the acceptation of null hypothesis. Regarding to the result, it means that there was no significant correlation between overall LLS and the English proficiency. In other words, LLS cannot be used simultaneously to predict the learner's TOEFL score.

\subsection{The Partial Prediction of Six Language Learning Strategy and English PROFICIENCY}

The researcher determined the partial prediction of LLS (memory, cognitive, compensation, metacognitive, affective and social strategy) toward English proficiency of the EFL learners. The compensation strategy with pvalue $=0.020<0.05$. In other words, compensation strategy can be used to predict the TOEFL score.

\begin{tabular}{|c|c|c|c|c|c|c|}
\hline \multirow[b]{2}{*}{ Model } & & \multicolumn{2}{|c|}{ Unstandardized Coefficients } & \multirow{2}{*}{\begin{tabular}{|l}
$\begin{array}{l}\text { Standardized } \\
\text { Coefficients }\end{array}$ \\
Beta
\end{tabular}} & \multirow[b]{2}{*}{$\mathrm{t}$} & \multirow[b]{2}{*}{ Sig. } \\
\hline & & $\bar{B}$ & Std. Error & & & \\
\hline \multirow[t]{7}{*}{1} & (Constant) & 424.917 & 42.687 & & 9.954 & .000 \\
\hline & Memory & -1.487 & 1.636 & -.180 & -.909 & .368 \\
\hline & Cognitive & -.275 & 1.399 & -.044 & -.197 & .845 \\
\hline & Compensation & 4.745 & 1.963 & .432 & 2.417 & .020 \\
\hline & Metacognitive & .057 & 1.822 & .008 & .031 & 975 \\
\hline & Affective & -3.066 & 2.232 & -.319 & -1.374 & .176 \\
\hline & Social & 2.310 & 2.055 & .236 & 1.124 & .267 \\
\hline
\end{tabular}

a. Dependent Variable: TOEFL

\section{Table 4 Coefficients Test Result of Multiple Regression Analysis between six Language Learning Strategy and English Proficiency}

Table 4 demonstrating that the compensation strategy is the only strategy showed the significant correlation with the TOEFL score. It is in line with the tvalue in the table 4 which the compensation strategies are the only strategies that have contribution to the TOEFL score while the other strategies have no contribution to the TOEFL score. In this strategy, the learners have tendency to use linguistic or other thing as a clue to guess the meaning of a vocabulary, switch into second language use gesture, coining the words and using synonym, and choose the topic that they have sufficient vocabulary or grammar in order to make direct communication using L2. 


\subsection{DisCUSSION}

The third most LLS used by the high proficient learners were metacognitive strategies, compensation strategies and cognitive strategies. This is in line with Rustam, Hamra and Weda (2015) that students of merchant marine studies polytechnics use metacognitive as the most frequently used, followed with compensation. In line with Jaradat and Bakrin (2016) that the strategy with highly used is metacognitive and cognitive. In line with Balci and Uguten (2018) that metacognitive and compensation were the most two strategies used by students of English prepatory class program at Necmettin Erbakan University in turkey.Goal setting strategy by identify the background content knowledge, preparing the vocabulary, structure and pronunciation (phaiboonnugulkij, 2008)

The discussion of this study is provided to make the interpretation of the findings. The discussion part discusses the relationship between six language learning strategies and English proficiency. The main finding is that LLS is not significantly correlated with English proficiency across and between proficiency levels. The present research is in line with previous study by Vertogen (2015) demonstrating that there was no correlation between language learning strategies and English grammar test scores. The LLS is the variable that can predict the achievement with the score less than $50 \%$, the value higher than the one found in this study where LLS can explain 18\% of English proficiency variance. The value reported here is also lower than the one reported in Uslu, Sahin \& Odemis's (2016) study that LLS can predict achievement $23 \%$.

In this study, the five language learning strategies showed no significant correlation with English proficiency as in contrast with some previous studies. This present study is contrasted with Balci \& Uguten (2017) finding out that LLS can affect language learning in positive way and increase achievement and the research by Dai (2016) that there is positive correlation between LLS and learning achievement. Based on Rismayana (2017) there is correlation between language learning strategies and proficiency level in the moderate level, and this is similar to the one reported in this study $(\mathrm{r}=.429)$. However, in Rismayana's (2017) study positive correlation was found between achievement score and the use of cognitive, compensation and metacognitive. This is in line with present study demonstrating significant correlation between

This study also found that compensation strategy is the only strategy which has significant correlation with English proficiency across participants. Based on research by Shabankareh and Hadizadeh (2011) that proficiency level affected the use of compensation, cognitive, metacognitive, and social strategies, but such effect was not observed in the use of memory and affective strategies. Dai (2016) also stated that affective strategy had no significant relationship with English proficiency, providing similar patterns as found in this study.

\section{CONCLUSION}

This present study revealed that all the EFL learners used strategies directly and indirectly. The most dominantly used strategies by EFL learners of vocational college are metacognitive strategy, followed by compensation strategy, and cognitive strategy. This study also revealed that LLS cannot simultaneously predict English proficiency. Therefore, it cannot confirm that LLS is able to enhance the student's language proficiency based on the identification of the relationship between LLS and the English proficiency through statistical significance. However, among six learning strategies, compensation strategy is the one that has significant correlation with English proficiency. Hereby, it is essential for EFL learners have tendency to use compensation strategies in which the learners guess the meaning when the learners do not understand the meaning rather than employing metacognitive strategies in which it generally needs much time in terms of planning, identifying and evaluating their own learning.

\section{REFERENCES}

Balci, O and Uguten, S. (2017). The Relationship between EFL Learners' LLS Use and Achievement. International Education Studies, Vol.11, No. 2, pp 1- 12.

Dai, H. (2017). An Empirical Study of Vocational Collage Students' English Learning Strategies. Atlantic Press: Advance in Economics, Business and Management Research, Vol. 30, pp 180183.

Dabaghi, A and Akvan, M. (2014). Explore the relationship between strategy used and ESP reading test performance of two university majors (Humanity vs Science). Academy Publisher: Theory and Practice in Language Studies, Vol. 4, No. 1, pp 121-128. 
Field, A. (2009). Discovering Statistics Using SPSS Third Edition. SAGE

Harya, T. D. (2017). Language Learning Strategy Taxonomy used by The Teacher in Teaching English. Rumah Jurnal IAIN Metro,pp 19-28

Hao, Y. C \& Nai Y. C. (2015). Effects of Language Learning Strategies and Learners' Motivation on Students' Learning Achievement. International Journal of English Language Education, Vol. 3, No. 2, pp 132- 143.

Hayati, N. (2015). A Study of English Language Learning Beliefs, Strategies, and English Academic Achievement of the ESP Students of STIENAS Samarinda. Dinamika Budaya: Journal of Education, Vol. 15 (2), pp 297- 323.

Jaradat, E. M. M., and Bakrin, M. (2016). Proficiency Level and Language Lerning Strategies Among Jordanian Students At Universiti Utara Malaysia. Proceeding of ICECRS, Vol. 1, pp 11211128.

Min, H. M. S and Pey, C. D. (2010). EFL Learners' Language Learning Strategy Use as a Predictor for Self-Directed Learning Readiness. The Journal of ASIA TEFL, Vol. 07, No. 02, pp 153-176.

Muhrofi, K. A \& Gunadi. (2015) Guru Bahasa Inggris Vokasi diera Global: Perlunya Perubahan Orientasi Pembelajaran. Prosiding Seminar Nasional Pendidikan Vokasi dalam Rangka Dies Natalis Ke- 54 FT UNY, pp 28- 36.

Oxford, R. (1990). Language Learning Strategies: What Every Teacher Should Know. Heinle and Heinle Publisher

Phaiboonnugulkij, M. (2018). Relationship Between Metacognitive Strategies and Characteristics of Profesional Tour Guide Trainees in English for Tourism. ALLS: Advances in Language and Literary Studies, Vol. 09, No. 03, pp 87-97.

Rachmawaty, N., Wello, M. B., Akil, M., Dollah, S. (2018). Do Cultural Intelligence and Language Learning Strategies Influence Students' English Language Proficiency?. Journal of Language Teaching and Research, Vol. 9, No. 3, pp. 655-663.

Rachmawati, D .L. (2015). Language Learning Strategies Adopted by English for Specific Purpose (ESP) Students in Merdeka University Malang. Malang: Universitas Brawijaya.

Rismayana. (2017). The Correlation Between LLS And Proficiency Level English Departement Students in UNM. ELITE: English and Literature Journal, Vol. 4, No. 2, pp 37- 50.

Rustam, N. S., Hamra, A., and Weda, S. (2015). The Language Learning Strategies Used by Students of Merchant Marine Studies Polytechnics Makassar. ELT Worldwide, Vol. 2, No. 2, pp 77- 94.

Saliu, B. (2013). Challenges for Learners/Teachers in The ESP Course for Legal Studies. SEEU Review, Vol. 09, No. 01, pp 1-8.

Shabankareh, N. N \& Hadizadeh, A. (2011). A Comparison of LLS between Bilingual and Monolingual Learners, Female and Male Learners, High School and University Students and High-Level and Low- Level Learners Learning English as a Foreign Language in Iran. International Journal of Arts and Science, Vol. 4, No. 8, pp 1-22.

Silalahi, U. (2015). Metode Penelitian Sosial Kuantitatif. Bandung: Refika Aditama.

Uslu, M. E., Sahin, E., Odemis, I. S. (2016). The Effect of Language Learning Strategies on Academic Achievement. Journal of Educational and Instructional Studies, Vol. 06, No. 3, pp 214-7463.

Vertogen, N. (2015). The relationship between the use of Language Learning Strategies and English Language Proficiency. Universiteit Gent.

Winangun, Kuntang. (2017). Pendidikan Vokasi Sebagai Pondasi Bangsa Menghadapi Globalisasi. Jurnal Taman Vokasi, Vol. 5, No. 1, pp 72- 78. 
